\title{
Implementasi Metode Tabu Search Dalam Penjadwalan Menggunakan Analisa Pieces
}

\author{
Made Suci Ariantini*, Ayu Manik Dirgayusari** \\ * Tenik Informatika, STMIK STIKOM Indonesia \\ ** Sistem Komputer, STMIK STIKOM Indonesia \\ *suci.ariantini@stiki-indonesia.ac.id,**ayu.manik@stiki-indonesia.ac.id
}

\begin{abstract}
Nowadays, Scheduling subjects is one of the first steps for starting the teaching and learning process in educational institutions. To do so, The role of teachers and school staff is very important and not easy because it takes a long time to compile it. SMK PGRI 4 Denpasar is one of the schools located in the city of Denpasar which is located on Jalan Kebo Iwa No 8, Padangsambian Kaja, Denpasar, Bali. It is a vocational high school that has a tourism expertise and computer engineering study program. Based on current results of observations and interviews, the process of making the subject schedules that run at SMK PGRI 4 Denpasar is still being done using Microsoft Excel, this has resulted in frequent errors in managing schedules such as conflicting schedule and it takes a long time to correct it. Tabu Search is an optimization method based on local search, where the search process moves from one solution to the next by selecting the best solution which is not classified as a prohibited solution. It is a combinatorial optimization problem-solving method that is incorporated into local search methods. This method aims to streamline the process of finding the best solution of a largescale (np-hard) combinatorial optimization problem. Tabu search method to optimize the process of making the subject schedule and combined using PIECES analysis (Performance, Information, Economic, Control, Efficiency, Services). From this analysis, several problems will be obtained, which in the end can be identified clearly and more specifically, so that we can conclude some suggestions that will help in designing a new and better system. The Tabu Search method can be used to optimize the process of making the subject schedules at SMK PGRI 4 Denpasar, so that the scheduling process will be more easier than using Microsoft Excel.
\end{abstract}

Keyword: Tabu Search, Penjadwalan, PIECES

\section{Introduction}

Kegiatan belajar mengajar tidak terlepas dari penentuan penjadwalan mata pelajaran. Setiap institusi pendidikan, terutama pada jenjang pendidikan dasar, menengah pertama maupun menengah umum, memiliki kesulitan tersendiri dalam penentuan penjadwalan mata pelajaran. Penjadwalan mata pelajaran merupakan pekerjaan rutin yang dilakukan oleh bagian kurikulum setiap menyambut tahun ajaran baru. Peran bagian kurikulum dalam pembuatan jadwal kegiatan belajar mengajar sangatlah penting dan tidak mudah karena jadwal yang akan diatur ulang terdiri dari data yang sangat banyak. Penjadwalan mata pelajaran adalah pengalokasian kegiatan pembelajaran yang terdiri dari mata pelajaran, guru, siswa, dan ruangan yang ditata ke dalam bentuk tabel waktu yang terdiri dari hari pembelajaran dalam satu minggu. Penjadwalan mata pelajaran di buat dengan membagi elemen pembelajaran dengan mengurangi resiko data yang sama agar tidak terjadi penumpukan jadwal yang sama. Penjadwalan mata pelajaran sangat bermanfaat dalam proses pembelajaran di setiap sekolah sehingga proses pembelajaran dapat berjalan dengan lancar dan teratur setiap harinya. Permasalahan penjadwalan mata pelajaran kerap terjadi di SMK PGRI 4 Denpasar yang merupakan salah satu sekolah yang bertempat di kota Denpasar yang berlokasi di Jalan Kebo Iwa No 8, Padangsambian Kaja, Denpasar, Bali. SMK PGRI 4 Denpasar merupakan salah satu sekolah menengah kejuruan yang memiliki program studi keahlian pariwisata dan teknik komputer. Berdasarkan hasil observasi dan wawancara yang dilakukan saat ini, proses pembuatan jadwal mata pelajaran yang berjalan pada SMK PGRI 4 Denpasar masih dikerjakan menggunkan Microsoft Excel, hal ini mengakibatkan seringnya terjadi kesalahan dalam mengelola jadwal seperti adanya jadwal guru yang sama atau berbenturan dalam satu waktu dan saat terjadi kesalahan atau adanya jadwal yang berbenturan dalam membuat penjadwalan dibutuhkan waktu yang cukup lama dalam memperbaiki jadwal yang salah atau bentrok tersebut. Tidak hanya jadwal yang berbenturan saja menjadi pertimbangan. Namun ada juga beberapa hal lain, seperti jumlah jam bagi siswa yang disesuaikan dengan 
tingkatan kelasnya dan jumlah keterbatasan guru. Tabu Search adalah sebuah metode optimasi yang berbasis pada local search, dimana proses pencarian bergerak dari satu solusi ke solusi berikutnya dengan cara memilih solusi terbaik yang tidak tergolong solusi terlarang [1]. Metode Tabu Search merupakan salah satu metode pemecahan permasalahan optimasi kombinatorial yang tergabung ke dalam local search methods. Metode ini bertujuan untuk mengefektifkan proses pencarian solusi terbaik dari suatu permasalahan optimasi kombinatorial yang berskala besar (bersifat np-hard). Tabu search memiliki kecepatan eksekusi lebih tinggi dibandingkan algoritma genetika karena tabu search tidak kembali pada solusi yang sudah dieksplorasi. Solusi yang sudah ada sebelumnya dicegah dengan menggunakan memori yang disebut dengan tabu list [2].

\subsection{Penelitian Terdahulu}

Adapun judul penelitian terdahulu yang digunakan sebagai acuan antara lain, Khairunnisa, dkk (2016) pernah melakukan penelitian dengan judul "Implementasi Algoritma Tabu Search Pada Aplikasi Penjadwalan Mata Pelajaran Studi kasus: SMA Negeri 4 Kendari”. Pada penelitian ini dijelaskan bahwa aplikasi yang dibuat berfokus pada data-data yang diperlukan seperti data kelas, data mata pelajaran, data guru dan data waktu untuk menghasilkan jadwal. Penelitian berikutnya dilakukan oleh Candra (2016) dengan judul "Penerapan Algoritma Tabu Search untuk Penjadwalan Mata Pelajaaran Di SMK Swasta Pelita-2 Aekkanopan”. dalam tulisannya menjelaskan bahwa pembuatan jadwal pelajaran dilakukan dengan menggunakan data guru, data kelas, dan data mata pelajaran dan berfokus pada metode yang digunakan untuk mencari solusi terbaik dari suatu permasalahan dalam menyusun penjadwalan. Penelitian yang akan penulis lakukan adalah merancang dan membangun Sistem Informasi Penjadwalan Mata Pelajaran pada SMK PGRI 4 Denpasar dengan Menggunakan Metode Tabu Search Berbasis Web. Hal yang mendasari dari penelitian sebelumnya yaitu terdapat persamaan pada proses pengolahan data dan hasil dari penjadwalan. Namun yang membedakan adalah sistem yang dirancang mampu memberikan laporan seperti adanya kalender akademik dan laporan jenjang pendidikan guru dalam bentuk grafik.

Tabel 1 Perbandingan Penelitian

\begin{tabular}{|c|c|c|c|}
\hline Penulis & $\begin{array}{l}\text { Mayang } \\
\text { Khairunnisa, Bambang } \\
\text { Pramono, Rizal Adi } \\
\text { Saputra }\end{array}$ & Leo Candra $\mathrm{S}$ & Putu Yahya Surya \\
\hline Tahun & 2016 & 2016 & 2019 \\
\hline Judul Penelitian & $\begin{array}{l}\text { Implementasi Algoritma } \\
\text { Tabu Search Pada } \\
\text { Aplikasi Penjadwalan } \\
\text { Mata Pelajaran Studi } \\
\text { Kasus: SMA Negeri } 4 \\
\text { Kendari }\end{array}$ & $\begin{array}{lr}\text { Penerapan } & \text { Algoritma } \\
\text { Tabu Search } & \text { utnuk } \\
\text { Penjadwalan } & \text { Mata } \\
\text { Pelajaran Di } & \text { SMK } \\
\text { Swasta } & \text { Pelita-2 } \\
\text { Aekkanopan } & \end{array}$ & $\begin{array}{lr}\text { Rancang } & \text { Bangun Sistem } \\
\text { Informasi } & \text { Penjadwalan } \\
\text { Mata } & \text { Pelajaran } \\
\text { Menggunakan Metode } \\
\text { Tabu Search Pada SMK } \\
\text { PGRI 4 Denpasar Berbasis } \\
\text { Web }\end{array}$ \\
\hline Lokasi Penelitian & SMA Negeri 4 Kendari & $\begin{array}{lll}\text { SMK Pelita } & 2 \\
\text { Aekkanopan } & \end{array}$ & SMK PGRI 4 Denpasar \\
\hline Objek Penelitian & Institusi Pendidikan & Institusi Pendidikan & Institusi Pendidikan \\
\hline Laporan & $\begin{array}{ll}\text { Penjadwalan mata } \\
\text { pelajaran }\end{array}$ & $\begin{array}{l}\text { Penjadwalan mata } \\
\text { pelajaran }\end{array}$ & $\begin{array}{lr}\text { Penjadwalan, } & \text { kalender } \\
\text { akademik dan jenjang } \\
\text { pendidikan guru }\end{array}$ \\
\hline Pengujian & Black box testing & - & Black box testing \\
\hline Pembuatan Sistem & Berbasis Dekstop & Berbasis Dekstop & Berbasis Website \\
\hline Fitur & $\begin{array}{l}\text { Master Data, Pengelolaan } \\
\text { Data }\end{array}$ & $\begin{array}{l}\text { Master Data, } \\
\text { Pengelolaan Data }\end{array}$ & $\begin{array}{l}\text { Master Data, Pengelolaan } \\
\text { Data }\end{array}$ \\
\hline
\end{tabular}

\section{Research Method}

Tahapan penelitian yang dilakukan yaitu dengan menggunakan metode observasi, wawancara, studi kepustakaan yang akan dilanjutkan dengan menganalisis data yang telah terkumpul menggunakan analisa PIECES untuk mengetahui solusi yang akan dirancang untuk pembuatan penjadwalan mata pelajaran dengan metode tabu search. Selanjutnya akan dibuatkan perancangan data dan perancangan user interface. Alur metode dapat dilihat pada Gambar 1. 


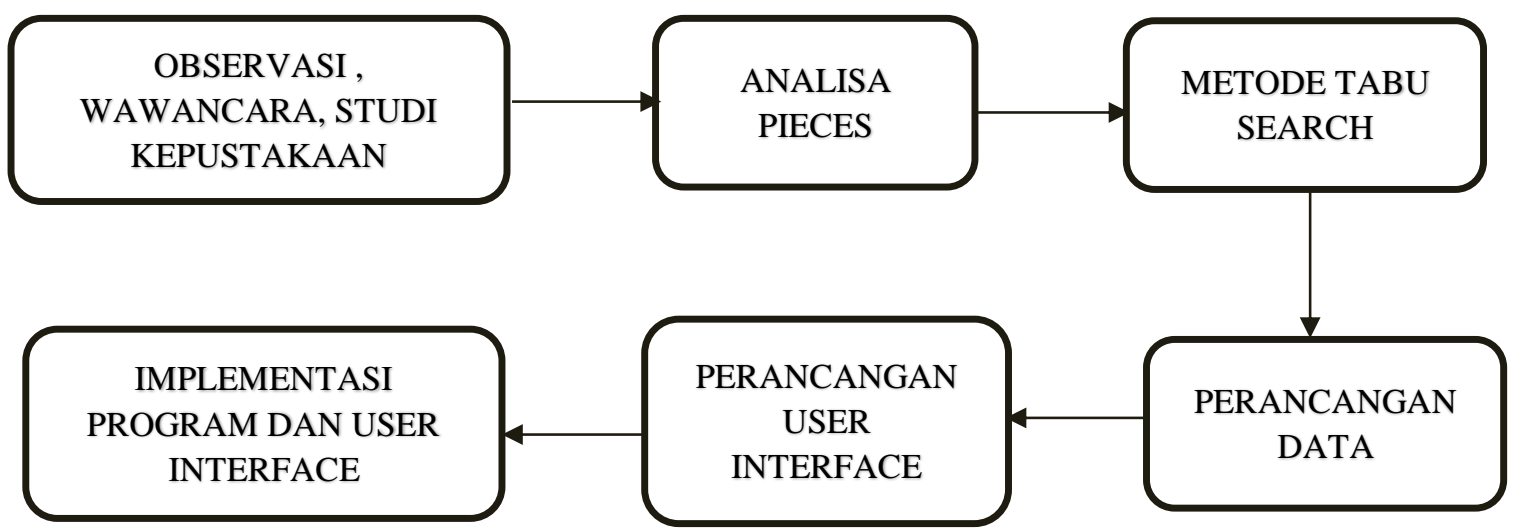

Gambar 1. Alur Metode Penelitian

Penerapan merupakan sebuah tindakan yang dilakukan baik secara individu maupun kelompok dengan maksud untuk mencapai tujuan yang telah dirumuskan. Pada penelitian ini, peneliti menggunakan metode tabu search untuk mengoptimasi pembuatan penjadwalan dan dikombinasi dengan menggunakan analisa PIECES (Performance, Information, Economic, Control, Efficiency, Services). Dari analisis ini, maka akan diperoleh beberapa masalah yang akhirnya dapat diketahui masalah utamanya dengan jelas dan lebih spesifik, sehingga dapat disimpulkan beberapa usulan yang akan membantu dalam perancangan sistem baru yang lebih baik.

Analisa PIECES adalah suatu sistem yang di gunakan untuk menganalisa system kerja pada suatu perusahaan atau organisasi. Menurut Wetherbe (2012) PIECES adalah untuk mengoreksi atau memperbaiki sistem informasi bagi pengambil keputusan dalam suatu organisasi. Analisis PIECES ini sangat penting untuk dilakukan sebelum mengembangkan sebuah sistem informasi karena dalam analisis ini biasanya akan ditemukan beberapa masalah utama maupun masalah yang bersifat gejala dari masalah utama. Ada 6 kriteria analisa PIECES yaitu
a. Kinerja (Performance)
b. Informasi (Information)
c. Ekonomi (Economic)
d. Kontrol (Control)
e. Efisiensi (Efficiency)
f. Pelayanan (Services)

Tabu Search adalah sebuah metode optimasi yang berbasis pada local search. Proses pencarian bergerak dari satu solusi ke solusi berikutnya, dengan cara memilih solusi terbaik neighbourhood solusi sekarang (current) yang tidak tergolong solusi terlarang (tabu). Kata "Tabu atau Taboo" berasal dari Tongan, suatu bahasa polinesia yang digunakan oleh suku Aborigin Pulau tonga untuk mengindikasikan suatu hal yang tidak boleh "disentuh" karena sakralnya. Tabu berarti larangan yang dipaksakan oleh kebudayaan sosial sebagai suatu tindakan pencegahan atau suatu yang dilarang karena berbahaya. Bahaya yang harus dihindari dalam Tabu Search adalah penjadwalan yang tidak layak, dan terjebak tanpa ada jalan keluar [3].

Prosedure dari metode Tabu Search adalah:

1. Pilih inisialisasi solusi i dalam $\mathrm{S}$. Set $i^{*}=\mathrm{i}$ dan $\mathrm{k}=0$.

2. Set $k=k+1$ dan buat subset $V^{*}$ dari solusi dalam $N(i, k)$ sedemikian sehingga kondisi $\mathrm{TS} \operatorname{tr}(\mathrm{i}, \mathrm{m}) \in$ Tr dilanggar $(r=i, \ldots, t)$ atau sedikitnya satu dari kondisi dipenuhi a $(i, m) \in A(i, m)$ terpenuhi $(r=i, \ldots, a)$.

3. Pilih yang terbaik $\mathrm{j}=\mathrm{i} \oplus \mathrm{m}$ dalam $\mathrm{V}^{*}$ (yang didasarkan pada atau fungsi yang sudah dirumuskan) dan set $\mathrm{i}=\mathrm{j}$.

4. Jika $\mathrm{f}(\mathrm{i})<\mathrm{f}\left(\mathrm{i}^{*}\right)$ maka set $\mathrm{i}^{*}=\mathrm{i}$.

5. Perbaharui tabu dan kondisi aspirasi

6. Jika tercapai kondisi pemberhentian, hentikan. Jika tidak, kembali ke langkah 2.

Algoritma Tabu search dalam bentuk flow chart bisa dilihat pada Gambar 2 berikut ini: 


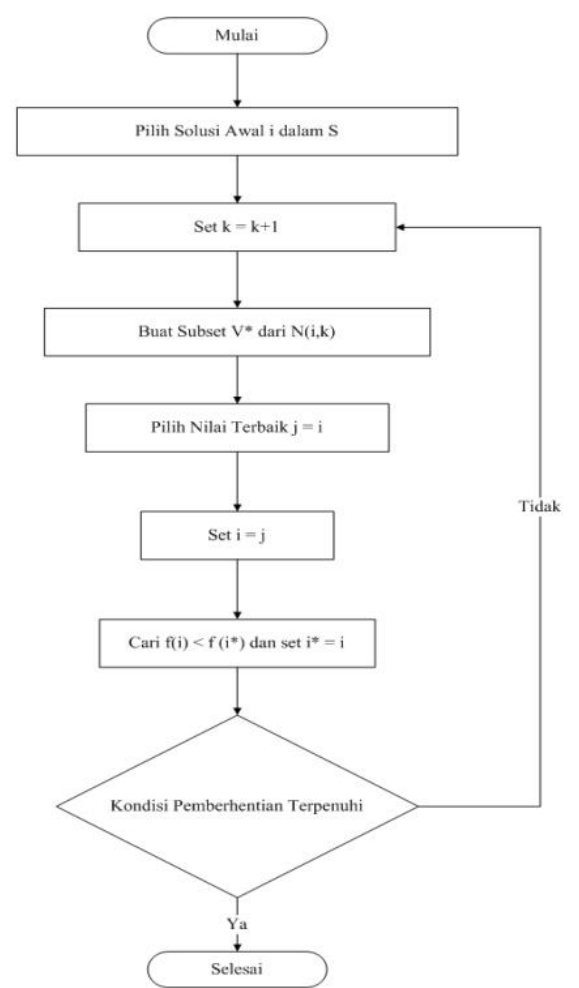

Gambar 2. Flow Chart Algoritma Tabu Search

\section{Result and Analysis}

\subsection{Analisa PIECES}

Dari hasil wawancara dengan Bapak Drs. I Ketut Suarya. M.Pd selaku Kepala Sekolah di SMK PGRI 4 Denpasar diperoleh informasi dan dianalisa menggunakan analisa PIECES dapat dilihat pada tabel 2.

Tabel 2. Hasil analisa PIECES

\begin{tabular}{|l|l|l|l|}
\hline No & Analisis Masalah & \multicolumn{1}{|c|}{ Sistem Lama } & \multicolumn{1}{c|}{ Sistem Baru } \\
\hline 1 & Performance & $\begin{array}{l}\text { Proses penjadwalan berlangsung } \\
\text { lama yaitu 1 minggu }\end{array}$ & $\begin{array}{l}\text { Proses pengerjaan penjadwalan di } \\
\text { dalam } \\
\text { sistem membutuhkan waktu 1-2 jam }\end{array}$ \\
\hline 2 & Information & $\begin{array}{l}\text { Informasi penjadwalan hanya bisa } \\
\text { dilihat di bagian tata usaha }\end{array}$ & $\begin{array}{l}\text { Informasi penjadwalan dapat } \\
\text { Dilihat oleh guru dan siswa secara } \\
\text { online }\end{array}$ \\
\hline 3 & Economy & $\begin{array}{l}\text { Pemborosan biaya kertas dan tinta } \\
\text { pada saat pendistribusian jadwal } \\
\text { yang telah selesai. Apabila ada } \\
\text { jadwal yang bentrok maupun } \\
\text { salah, maka akan di cetak ulang } \\
\text { lagi. }\end{array}$ & $\begin{array}{l}\text { Proses penjadwalan tidak } \\
\text { membutuhkan dana tambahan } \\
\text { untuk pendistribusian jadwal, } \\
\text { Karena data penjadwalan dapat } \\
\text { diakses dengan mudah melalui } \\
\text { sistem oleh user }\end{array}$ \\
\hline 4 & Control & $\begin{array}{l}\text { Pada sistem yang lama, data } \\
\text { sering tidak disimpan maupun } \\
\text { tidak sengaja terhapus } \\
\text { yang disebabkan kelalaian } \\
\text { manusia. Tidak adanya keamanan } \\
\text { data membuat siapapun dapat } \\
\text { membuka file excel penjadwalan. }\end{array}$ & $\begin{array}{l}\text { Sistem ini ming } \\
\text { pengamanan data melalui user login. } \\
\text { Sehingga memudahkan } \\
\text { pengontrolan data sehingga tidak } \\
\text { dapat diakses oleh sembarang user. }\end{array}$ \\
\hline 5 & Efficient & $\begin{array}{l}\text { Waktu yang dibutuhkan untuk } \\
\text { mengolah penjadwalan }\end{array}$ & $\begin{array}{l}\text { Waktu yang dibutuhkan untuk } \\
\text { mengolah }\end{array}$ \\
\hline
\end{tabular}




\begin{tabular}{|l|l|l|l|}
\hline & & membutuhkan waktu 1 minggu & $\begin{array}{l}\text { penjadwalan di dalam sistem } \\
\text { membutuhkan waktu 1-2 jam }\end{array}$ \\
\hline 6 & Services & $\begin{array}{l}\text { Hasil penjadwalan membutuhkan } \\
\text { waktu 1 minggu untuk dapat di } \\
\text { distribusikan. }\end{array}$ & $\begin{array}{l}\text { Hasil penjadwalan membutuhkan } \\
\text { waktu 1-2 jam, sehingga } \\
\text { pendistribusian online menjadi } \\
\text { lebih cepat. }\end{array}$ \\
\hline
\end{tabular}

\subsection{Data Flow Diagram}

Pada data flow diagram ini dapat diartikan bahwa admin dapat melakukan login dengan data user name dan dapat melakukan pengolahan data seperti data user, guru, mata pelajaran, jam pelajaran dan data kelas. Guru dapat melakukan login dan mengolah data guru itu sendiri, sedangkan siswa hanya dapat melihat jadwal mata pelajaran yang ada di sistem tersebut. Data Flow Diagram dapat dilihat pada gambar 3.

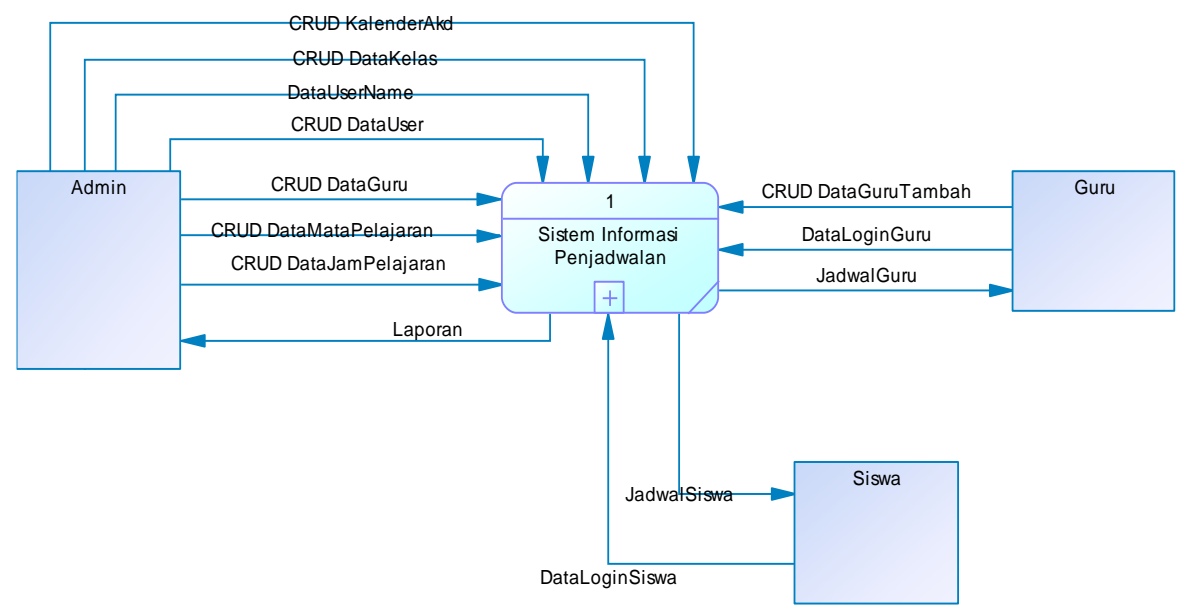

Gambar 3. Data Flow Diagram

\subsection{Entity Relationship Diagram}

Sistem penjadwalan mata pelajaran memiliki beberapa entitas di dalam alurnya yang terdiri dari entitas admin, guru, siswa, jadwal, jam pelajaran, kelas, mata pelajaran, dan kalender akademik. Entitas admin berelasi dengan entitas jadwal dan kalender akademik, entitas jadwal berelasi dengan enititas admin, siswa dan guru, entitas siswa berelasi dengan entitas entitas jadwal dan kalender akademik, entitas kalender akademik berelasi dengan entitas guru dan siswa, entitas guru berelasi dengan entitas kalender akademik, entitas jam pelajaran berelasi dengan entitas kelas, entitas kelas berelasi dengan entitas jam pelajaran dan mata pelajaran, entitas mata pelajaran berelasi dengan entitas jadwal dan kelas. Entity Relationship Diagram dapat dilihat pada gambar 4. 


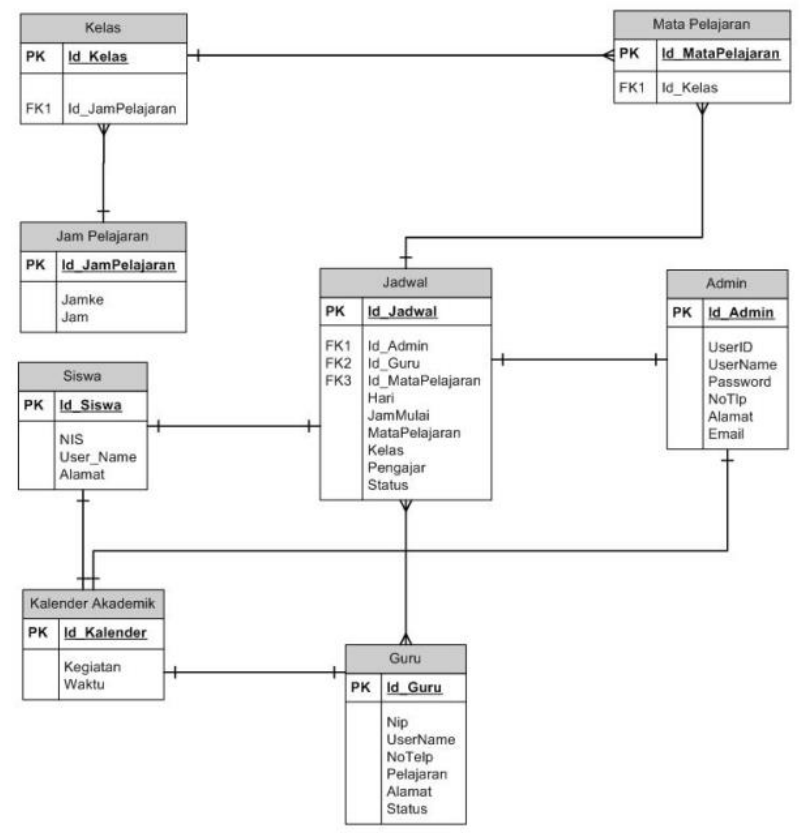

Gambar 4. Entity Relationship Diagram

\subsection{Implementasi dan pengujian Antarmuka}

Proses implementasi dilakukan berdasarkan perancangan yang telah dibuat sebelumnya sehingga menghasilkan beberapa menu. Untuk mengetahui keberhasilan fungsionalitas dari masing-masing menu, maka dilakukan pengujian yaitu dengan menggunakan metode blacbox testing. Adapun hasilnya akan dijabarkan pada subbab ini.

1. Implementasi dan pengujian Halaman Login

User akan menginputkan username dan passwword yang telah terdaftar dan terdapat button sign in untuk masuk kedalam sistem tersebut. Tampilan form login dapat dilihat pada gambar 5.

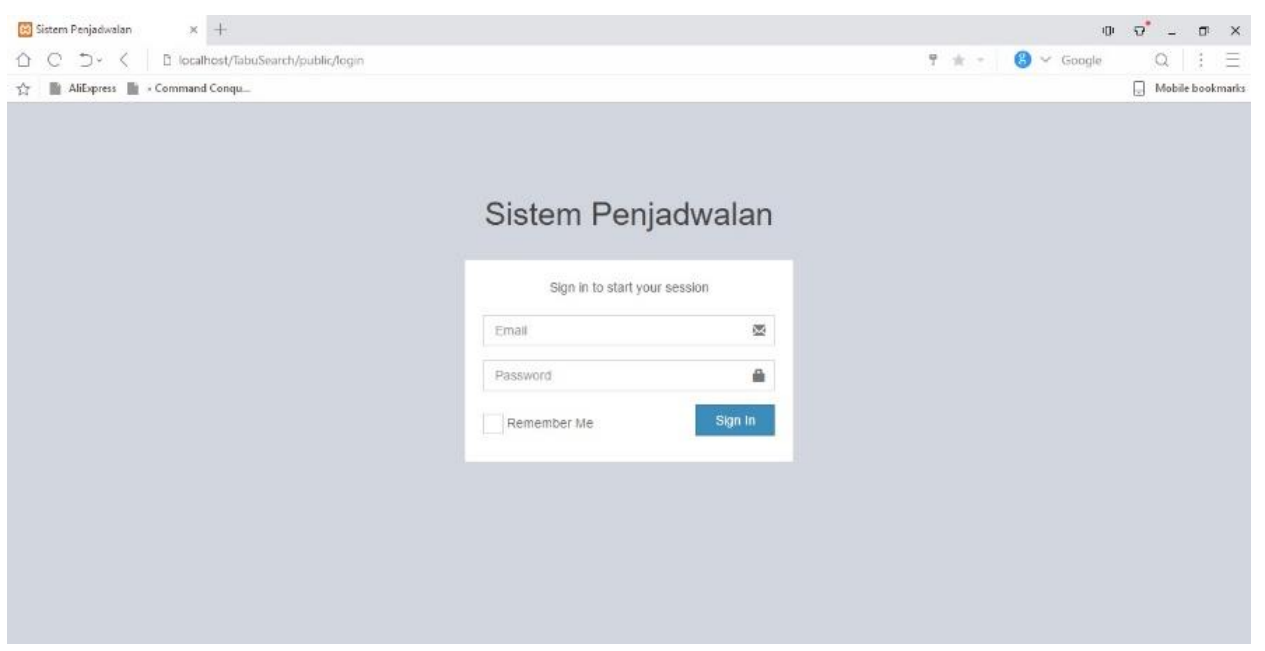

Gambar 5. Halaman Login

Dan hasil pengujian menu login dapat dilihat pada tabel 3.

Tabel 3. Pengujian form menu login

\begin{tabular}{|l|l|l|}
\hline \multicolumn{1}{|c|}{ Skenario Pengujian } & Hasil yang Diharapkan & Hasil Uji \\
\cline { 1 - 1 } $\begin{array}{l}\text { Mengisi username dan } \\
\text { password yang sesuai }\end{array}$ & $\begin{array}{l}\text { 1. } \\
\text { 2. User berhasil login } \\
\text { Klik button sign in } \\
\text { utama }\end{array}$ & Sesuai Harapan \\
$\begin{array}{l}\text { Mengisi } \text { username dan } \\
\text { password yang tidak sesuai }\end{array}$ & \multirow{2}{*n}{$\begin{array}{l}\text { User gagal login } \\
\text { Klik button sign in }\end{array}$} & Sesuai Harapan \\
\hline
\end{tabular}


2. Halaman Menu Mata Pelajaran

Halaman Menu Mata Pelajaran merupakan tampilan menu mata pelajaran, dimana di menu tersebut admin dapat menambah, mengubah dan menghapus data mata pelajaran. Tampilan menu mata pelajaran dapat dilihat pada gambar 6 .

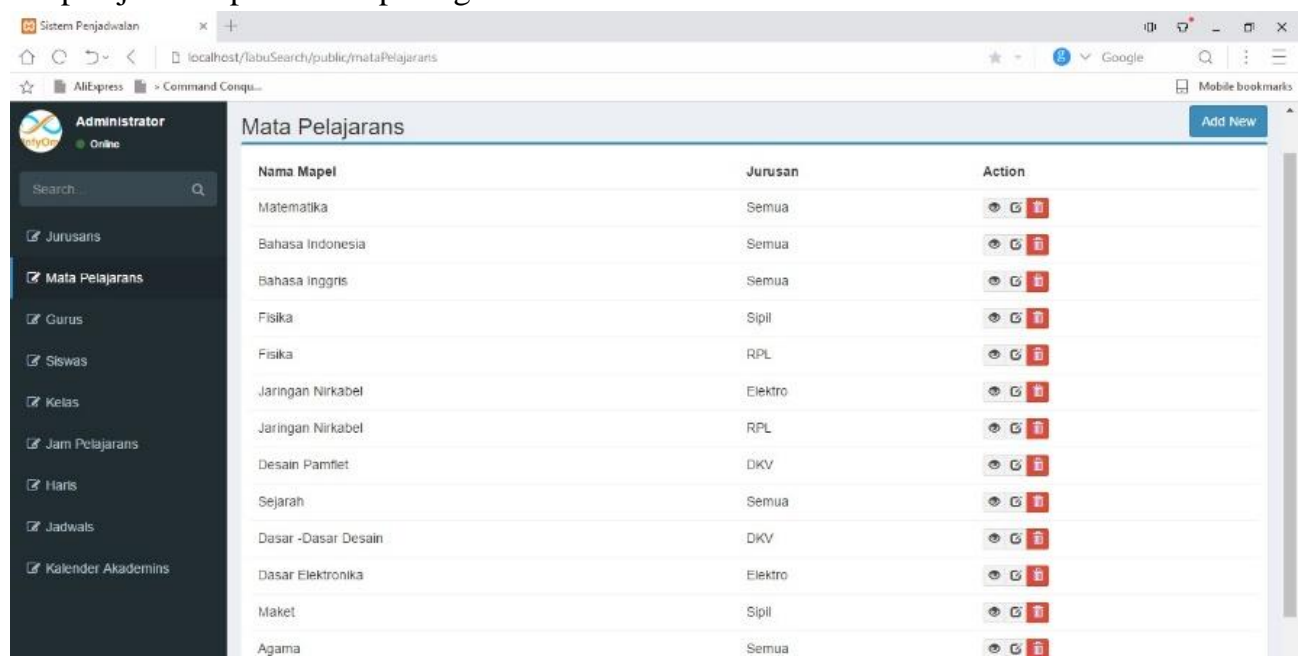

Gambar 6. Tampilan halaman menu mata pelajaran

Dan hasil pengujian menu mata pelajaran dapat dilihat pada tabel 3.

Tabel 3. Pengujian menu mata pelajaran

\begin{tabular}{|l|l|l|}
\hline Skenario Pengujian & \multicolumn{1}{|c|}{ Hasil yang Diharapkan } & \multicolumn{1}{c|}{ Hasil Uji } \\
\hline $\begin{array}{l}\text { Klik Menu Mata } \\
\text { Pelajaran }\end{array}$ & $\begin{array}{l}\text { Sitem menampilkan menu data mata } \\
\text { pelajaran }\end{array}$ & Sesuai Harapan \\
\hline Klik button add new & $\begin{array}{l}\text { Sistem menampilkan form tambah } \\
\text { mata pelajaran }\end{array}$ & Sesuai Harapan \\
\hline Klik icon hapus & $\begin{array}{l}\text { Sitem akan menghapus data mata } \\
\text { pelajaran }\end{array}$ & Sesuai Harapan \\
\hline Klik icon edit & $\begin{array}{l}\text { Sistem akan mengedit data mata } \\
\text { pelajaran }\end{array}$ & Sesuai Harapan \\
\hline Klik icon detail & $\begin{array}{l}\text { Sistem akan menampilkan detail data } \\
\text { mata pelajaran }\end{array}$ & Sesuai Harapan \\
\hline
\end{tabular}

3. Halaman Menu Jam Mata Pelajaran

Halaman menu jam mata pelajaran dimana pada menu jam mata pelajaran ini, admin dapat mengubah jam pelajaran, menghapus jam pelajaran dan menambah jam pelajaran. Tampilan menu jam mata pelajaran dapat dilihat pada gambar 7 . 


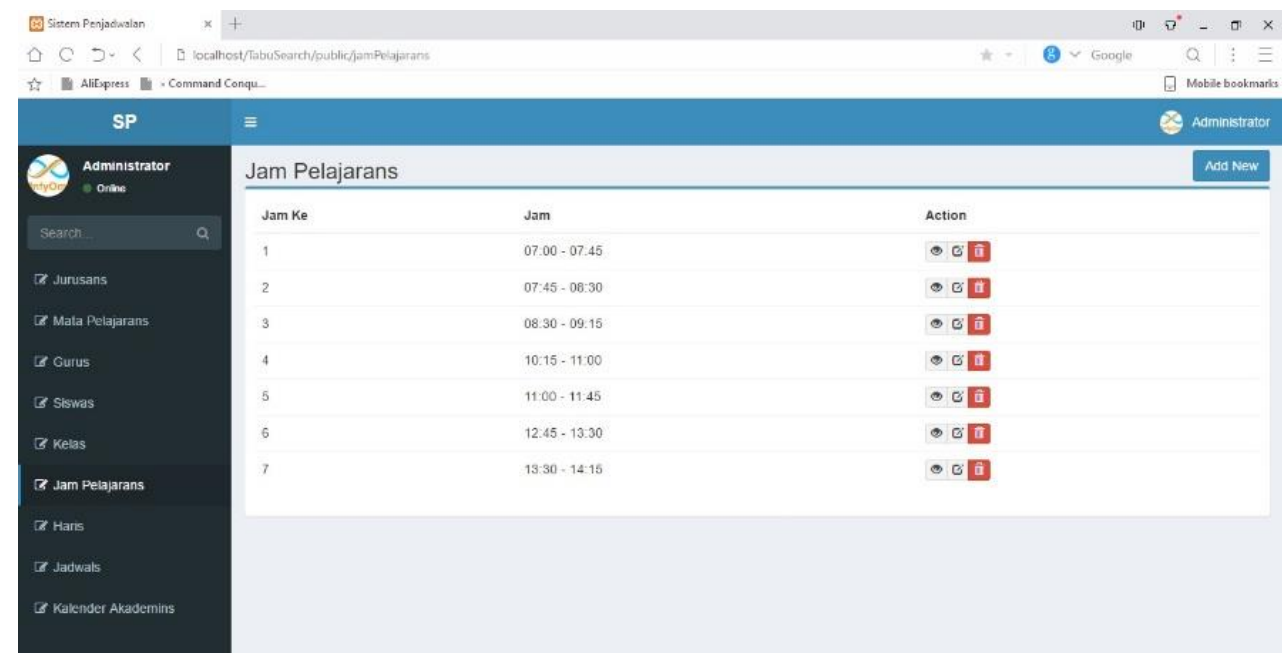

Gambar 7. Tampilan menu jam mata pelajaran

Dan hasil pengujian menu jam mata pelajaran dapat dilihat pada tabel 4.

Tabel 4. Pengujian menu jam mata pelajaran

\begin{tabular}{|l|l|l|}
\hline \multicolumn{1}{|c|}{ Skenario Pengujian } & \multicolumn{1}{|c|}{ Hasil yang Diharapkan } & \multicolumn{1}{c|}{ Hasil Uji } \\
\hline Klik Menu Jam Pelajaran & $\begin{array}{l}\text { Sitem menampilkan menu data jam } \\
\text { pelajaran }\end{array}$ & Sesuai Harapan \\
\hline Klik button add new & $\begin{array}{l}\text { Sistem menampilkan form tambah data } \\
\text { jam pelajaran }\end{array}$ & Sesuai Harapan \\
\hline Klik icon hapus & $\begin{array}{l}\text { Sitem akan menghapus data jam } \\
\text { pelajaran }\end{array}$ & Sesuai Harapan \\
\hline Klik icon edit & $\begin{array}{l}\text { Sistem akan mengedit data jam } \\
\text { pelajaran }\end{array}$ & Sesuai Harapan \\
\hline Klik icon detail & $\begin{array}{l}\text { Sistem akan menampilkan detail data } \\
\text { jam pelajaran }\end{array}$ & Sesuai Harapan \\
\hline
\end{tabular}

4. Halaman Menu Penjadwalan

Haman menu penjadwalan yaitu dimana admin dapat mengubah jadwal jika tidak sesuai dengan cara klik button generate maka sistem akan membuat jadwal baru dengan menggunakan metode tabu search yang akan memuncul jadwal baru yang berbeda, jika jadwal sudah sesuai maka admin dapat menyimpan jadwal tersebut dengan cara klik button save. Tampilan halaman menu penjadwalan dapat dilihat pada gambar 8 .

Searich
Q Jurusans

Gambar 8. Tampilan halaman menu penjadwalan

Dan pengujian menu penjadwalan dapat dilihat pada tabel 5. 
Tabel 5. Pengujian menu penjadwalan

\begin{tabular}{|l|l|c|}
\hline Skenario Pengujian & \multicolumn{1}{|c|}{ Hasil yang Diharapkan } & \multicolumn{1}{c|}{ Hasil Uji } \\
\hline Klik Menu Jadwal & Sitem menampilkan menu jadwal & Sesuai Harapan \\
\hline Klik button Generate & $\begin{array}{l}\text { Sistem akan membuat jadwal } \\
\text { menggunakan metode tabu search }\end{array}$ & Sesuai Harapan \\
\hline Klik button Save & $\begin{array}{l}\text { Sitem akan menyimpan data jadwal } \\
\text { yang sudah sesuai }\end{array}$ & Sesuai Harapan \\
\hline
\end{tabular}

5. Halaman Jadwal Guru

Halaman menu jadwal guru dimana guru dapat melihat dimana jadwal mengajarnya. Tampilan halaman menu jadwal guru dapat dilihat pada gambar 9.

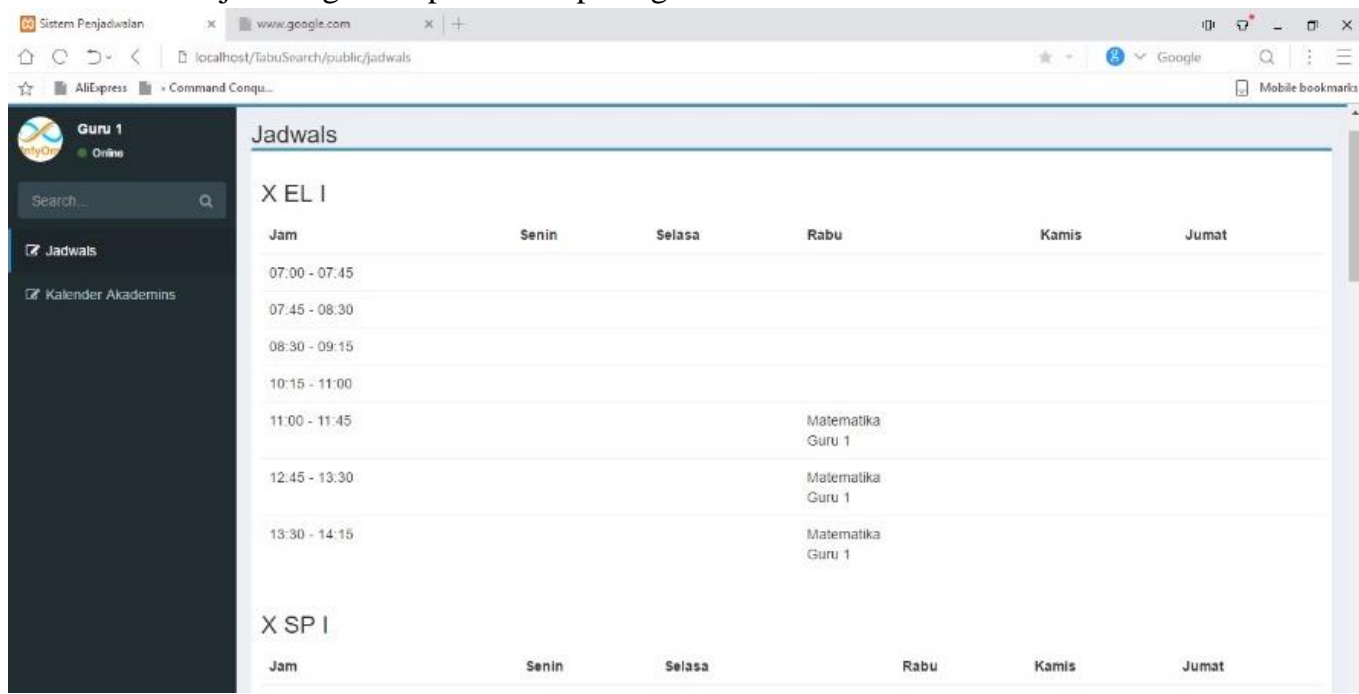

Gambar 9. Halaman menu jadwal guru

Dan pengujian terhadap menu jadwal guru dapat dilihat pada tabel 6.

Tabel 6. Pengujian menu jadwal guru

\begin{tabular}{|l|l|l|}
\hline Skenario Pengujian & \multicolumn{1}{|c|}{ Hasil yang Diharapkan } & \multicolumn{1}{c|}{ Hasil Uji } \\
\hline Klik Menu Guru & Sitem menampilkan menu data guru & Sesuai Harapan \\
\hline Klik button add new & Sistem menampilkan form tambah guru & Sesuai Harapan \\
\hline Klik icon hapus & Sitem akan menghapus data guru & Sesuai Harapan \\
\hline Klik icon edit & Sistem akan mengedit data guru & Sesuai Harapan \\
\hline Klik icon detail & $\begin{array}{l}\text { Sistem akan menampilkan detail data } \\
\text { guru }\end{array}$ & Sesuai Harapan \\
\hline
\end{tabular}

6. Halaman Jadwal Siswa

Halaman siswa dimana siswa dapat melihat jadwal mata pelajaran mereka sesuai dengan kelas dan jurusan siswa tersebut. Tampilan halaman jadwal siswa dapat dilihat pada gambar 10. 


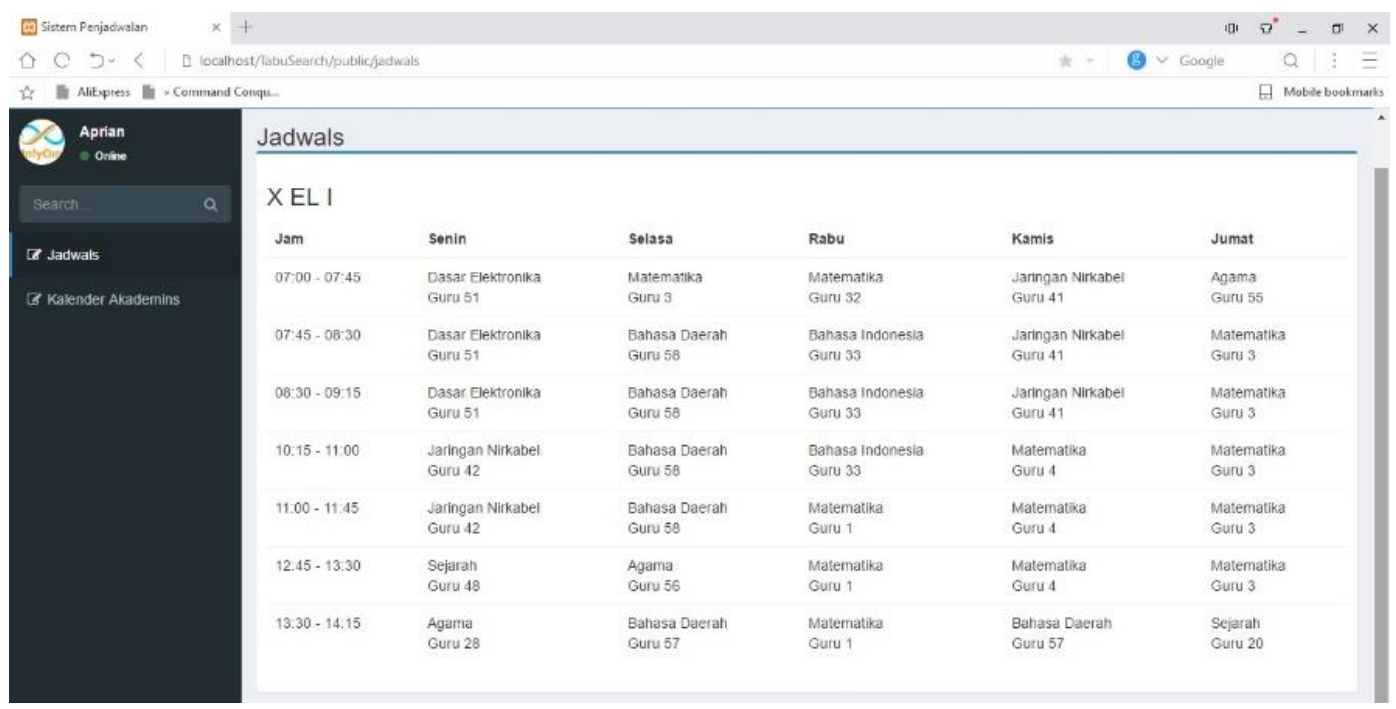

Gambar 10. Tampilan halaman jadwal siswa

Dan hasil pengujian jadwal siswa dapat dilihat pada tabel 7.

Tabel 7. Pengujian pada menu jadwal siswa

\begin{tabular}{|l|l|l|}
\hline Skenario Pengujian & \multicolumn{1}{|c|}{ Hasil yang Diharapkan } & \multicolumn{1}{|c|}{ Hasil Uji } \\
\hline Klik Menu Siswa & Sitem menampilkan menu data siswa & Sesuai Harapan \\
\hline Klik button add new & $\begin{array}{l}\text { Sistem menampilkan form tambah } \\
\text { siswa }\end{array}$ & Sesuai Harapan \\
\hline Klik icon hapus & Sitem akan menghapus data siswa & Sesuai Harapan \\
\hline Klik icon edit & Sistem akan mengedit data siswa & Sesuai Harapan \\
\hline Klik icon detail & $\begin{array}{l}\text { Sistem akan menampilkan detail data } \\
\text { siswa }\end{array}$ & Sesuai Harapan \\
\hline
\end{tabular}

\section{Conclusion}

Dari penelitian yang telah dilakukan dapat disimpulkan beberapa hal. Adapun kesimpulannya adalah sebagai berikut :

1. Sistem informasi penjadwalan mata pelajaran yang menggunakan metode Algoritma Tabu Search dapat mengoptimalkan proses pembelajaran dengan mengurangi adanya bentrok jadwal.

2. Metode Tabu Search dapat digunakan untuk mengoptimalkan penyusunan jadwal mata pelajaran pada SMK PGRI 4 Denpasar sehingga dapat mempermudah proses penjadwalan yang dilakukan dibanding dengan memakai Microsoft Excel.

\section{References}

[1] R. A. S. Mayang Putri Khairunnisa, Bambang Pramono, "Implementasi Algoritma Tabu Search pada Aplikasi Penjadwalan Mata Pelajaran (Studi Kasus: SMA NEGERI 4 Kendari),” Informatics Eng.

Dep. Halu Oleo Univ., vol. 2, no. 2, pp. 31-39, 2017.

[2] N. Tiandini and W. Anggraeni, "Penerapan Metode Kombinasi Algoritma Genetika dan Tabu Search dalam Optimasi Alokasi Kapal Peti Kemas (Studi Kasus : PT. XYZ),” J. Tek. ITS, vol. 6, no. 1, pp. 188-191, 2017.

[3] L. Candra, "Penerapan algoritma tabu search untuk penjadwalan mata pelajaran di smk swasta pelita2 aekkanopan," JURIKOM (Jurnal Ris. Komputer), vol. 3, no. 6, pp. 74-79, 2016.

[4] Wetherbe, James.2012. Systems Analysis and Design: Traditional, Best Practices 4th Ed.

[5] Hutahaean, Japerson. 2014. Konsep Sistem Informasi, Edisi Peratama, Cetakan Ke-1. Yogyakarta : Deepublish.

[6] Satzinger, J W., Jackson, R.B. \& Burd, S. D. 2012. System Analysis and Design with Unified Process. USA: Cengage Learning. 